\title{
Assessment of $\mathrm{Cr}(\mathrm{VI})$-Induced Cytotoxicity and Genotoxicity Using High Content Analysis
}

\author{
Chad M. Thompson ${ }^{1 *}$, Yuriy Fedorov ${ }^{2}$, Daniel D. Brown ${ }^{2}$, Mina Suh ${ }^{3}$, Deborah M. Proctor ${ }^{3}$, Liz Kuriakose ${ }^{1}$, \\ Laurie C. Haws ${ }^{4}$, Mark A. Harris ${ }^{1}$
}

1 ToxStrategies, Katy, Texas, United States of America, 2 Thermo Fisher Scientific, Pittsburgh, Pennsylvania, United States of America, 3 ToxStrategies, Austin, Texas, United States of America, 4 ToxStrategies, Rancho Santa Margarita, California, United States of America

\begin{abstract}
Oral exposure to high concentrations of hexavalent chromium $[\mathrm{Cr}(\mathrm{VI})]$ induces intestinal redox changes, villus cytotoxicity, crypt hyperplasia, and intestinal tumors in mice. To assess the effects of $\mathrm{Cr}(\mathrm{VI})$ in a cell model relevant to the intestine, undifferentiated (proliferating) and differentiated (confluent) Caco-2 cells were treated with $\mathrm{Cr}(\mathrm{VI})$, hydrogen peroxide or rotenone for 2-24 hours. DNA damage was then assessed by nuclear staining intensity of 8-hydroxydeoxyguanosine (8$\mathrm{OHdG})$ and phosphorylated histone variant $\mathrm{H} 2 \mathrm{AX}(\gamma-\mathrm{H} 2 \mathrm{AX})$ measured by high content analysis methods. In undifferentiated Caco-2, all three chemicals increased 8-OHdG and $\gamma-\mathrm{H} 2 \mathrm{AX}$ staining at cytotoxic concentrations, whereas only 8-OHdG was elevated at non-cytotoxic concentrations at $24 \mathrm{hr}$. Differentiated Caco-2 were more resistant to cytotoxicity and DNA damage than undifferentiated cells, and there were no changes in apoptotic markers p53 or annexin- $\mathrm{V}$. However, $\mathrm{Cr}(\mathrm{VI})$ induced a dose-dependent translocation of the unfolded protein response transcription factor ATF6 into the nucleus. Micronucleus (MN) formation was assessed in CHO-K1 and A549 cell lines. $\mathrm{Cr}(\mathrm{VI})$ increased MN frequency in CHO-K1 only at highly cytotoxic concentrations. Relative to the positive control Mitomycin- $\mathrm{C}, \mathrm{Cr}(\mathrm{VI})$ only slightly increased $\mathrm{MN}$ frequency in A549 at mildly cytotoxic concentrations. The results demonstrate that $\mathrm{Cr}(\mathrm{VI})$ genotoxicity correlates with cytotoxic concentrations, and that $\mathrm{H} 2 \mathrm{AX}$ phosphorylation occurs at higher concentrations than oxidative DNA damage in proliferating Caco-2 cells. The findings suggest that in vitro genotoxicity of $\mathrm{Cr}(\mathrm{VI})$ is primarily oxidative in nature at low concentrations. Implications for in vivo intestinal toxicity of $\mathrm{Cr}(\mathrm{VI})$ will be discussed.
\end{abstract}

Citation: Thompson CM, Fedorov Y, Brown DD, Suh M, Proctor DM, et al. (2012) Assessment of Cr(VI)-Induced Cytotoxicity and Genotoxicity Using High Content Analysis. PLoS ONE 7(8): e42720. doi:10.1371/journal.pone.0042720

Editor: Baohong Zhang, East Carolina University, United States of America

Received March 20, 2012; Accepted July 10, 2012; Published August 8, 2012

Copyright: $\odot 2012$ Thompson et al. This is an open-access article distributed under the terms of the Creative Commons Attribution License, which permits unrestricted use, distribution, and reproduction in any medium, provided the original author and source are credited.

Funding: This work was supported by the $\mathrm{Cr}(\mathrm{VI})$ Panel of the American Chemistry Council. The funders had no role in study design, data collection and analysis, decision to publish, or preparation of any manuscript. The funders were given the opportunity to review the draft study design as it went through an external peer review process and draft manuscripts at the time of external peer review. The purpose of such review was to allow input on the clarity of the science presented but not in interpretation of the research findings. The researchers' scientific conclusions and professional judgments were not subject to the funders' control.

Competing Interests: YF and DDB were formerly employed by Thermo Fisher Scientific, which provided materials used in this study. All other authors are employed by ToxStrategies, Inc., which provides consultancy to industrial and governmental organizations. Additionally, this work was funded by The Hexavalent Chromium Panel of the American Chemistry Council. This does not alter the authors' adherence to all the PLoS ONE policies on sharing data and materials.

*E-mail: cthompson@toxstrategies.com

\section{Introduction}

Hexavalent chromium [Cr(VI)] inhalation exposure is a wellaccepted risk factor for human lung cancer [1]. Oral exposure to very high concentrations of $\mathrm{Cr}(\mathrm{VI})$ in drinking water was recently shown to induce intestinal tumors in mice $[2,3]$. Upon ingestion, $\mathrm{Cr}(\mathrm{VI})$ is reduced to the more inert trivalent form, $\mathrm{Cr}(\mathrm{III})$, by gastric fluids due to the low $\mathrm{pH}$ and presence of biomolecules and foodstuffs [4,5]. Unreduced $\mathrm{Cr}(\mathrm{VI})$ is absorbed from the intestinal lumen via anion transporters and reduced intracellularly by low molecular weight thiols (e.g. GSH), antioxidants (e.g. ascorbate), and other molecules [6,7]. $\mathrm{Cr}(\mathrm{VI})$ is generally unreactive toward DNA, whereas $\mathrm{Cr}$ (III) either itself or as binary ligands (e.g. CrGSH) can react with DNA. Cr(VI) reduction to intermediate forms such as $\mathrm{Cr}(\mathrm{V})$ and $\mathrm{Cr}(\mathrm{IV})$ can elicit changes in cellular redox status either through depletion of thiols and antioxidants or generation of reactive oxygen species (ROS). Thus, under various in vitro exposure scenarios $\mathrm{Cr}(\mathrm{VI})$ has been shown to induce a wide spectrum of genotoxic lesions $[8,9,10,11,12]$. In addition, recent studies indicate that continuous passage of certain cells in low concentrations of $\mathrm{Cr}(\mathrm{VI})$ in vitro can result in transformation to malignant cells $[13,14,15]$. It is thus important to understand the risk that $\mathrm{Cr}(\mathrm{VI})$ ingestion in drinking water may have on intestinal carcinogenesis at typical environmental exposure levels.

Despite evidence for potential genotoxic effects of $\mathrm{Cr}(\mathrm{VI})$ in vitro, in vivo evidence for genotoxicity following oral exposure is equivocal [16]. The National Toxicology Program (NTP) conducted four in vivo micronucleus $(\mathrm{MN})$ tests in three strains of mice that were exposed to $\mathrm{Cr}(\mathrm{VI})$ in drinking water for three months and reported positive $\mathrm{MN}$ formation only in one of the four studies, viz. in transgenic strain am3-C57BL/6 [17]. This mouse strain contains a transgene for detecting forward and reverse mutations; however, mutation analysis was not performed $[2,17]$. Similar negative MN findings were observed in other studies $[18,19]$. Mice chronically exposed to very high concentrations of $\mathrm{Cr}(\mathrm{VI})$ in drinking water developed small intestinal tumors (mostly adenomas) that were detected, in all but one instance, only at study termination [2]. Histopathological analyses indicated that $\mathrm{Cr}(\mathrm{VI})$ induced intestinal damage and regenerative cell proliferation $[2,3]$, 
and such effects can be seen at carcinogenic concentrations after only 7 days of exposure [20]. In contrast, rats exposed to the same $\mathrm{Cr}(\mathrm{VI})$ drinking water concentrations did not develop intestinal damage, cell proliferation or intestinal tumors [2,3,17]. Together, these observations suggest that $\mathrm{Cr}(\mathrm{VI})$ was not very efficient at causing DNA mutation, malignancy or death, and that intestinal damage and hyperplasia was a major factor in the tumorigenesis in mice.

It is well accepted that cytotoxicity and regenerative hyperplasia are major contributors to carcinogenesis [21,22,23]. We have previously hypothesized that the mode of action (MOA) for $\mathrm{Cr}(\mathrm{VI})$-induced carcinogenicity in the mouse small intestine is the result of cytotoxicity and hyperplasia [16] as opposed to mutagenic mechanisms proposed by others [12,24]. Evidence for this includes redox changes and villus cytotoxicity at lower $\mathrm{Cr}(\mathrm{VI})$ concentrations than those that increase crypt hyperplasia [20], induction of Nrf2 signaling at low $\mathrm{Cr}(\mathrm{VI})$ concentrations [25], lack of $\mathrm{MN}$ formation in duodenal crypts after 7 or 90 days of exposure to $\mathrm{Cr}(\mathrm{VI})$ [26], as well as lack of in vivo $K$-ras codon 12 GAT mutations in the mouse duodenum after 90 days of exposure [27]. Given the preponderance of data indicating that $\mathrm{Cr}(\mathrm{VI})$ is genotoxic in vitro, we attempted to recapitulate the in vivo intestinal mucosa with an in vitro cell model in order to a) explore whether there are differences in response to $\mathrm{Cr}(\mathrm{VI})$ in proliferating and differentiated intestinal cells, and b) examine whether oxidative DNA damage and H2AX phosphorylation were present at noncytotoxic concentrations.

The mucosa of the small intestine is comprised of mature differentiated villus enterocytes that are directly exposed to the intestinal lumen, and poorly differentiated proliferative enterocytes that reside in glands of Leiberkühn (i.e. crypts) below the luminal surface $[28,29]$. To create an in vitro model of these two cell populations, the human colorectal adenocarcinoma Caco-2 cell line was grown for either 1 or 21 days, and then exposed to $\mathrm{Cr}(\mathrm{VI})$ for up to 24 hours. In short-term culture, Caco-2 cells are undifferentiated and proliferating, and thus closely resemble intestinal crypt epithelial cells. Although Caco-2 cells originate from the colon, when grown to post-confluency ( $\sim 21$ days $)$ they spontaneously differentiate and develop morphological characteristics of the small intestine including polarity, intercellular junctions, microvilli, and express markers for mature enterocytes such as brush border hydrolases; as such, Caco-2 are a wellaccepted model for studying intestinal absorption, metabolism and cytotoxicity [30,31,32,33,34,35]. A previous study reported that chromium (unspecified valence) increased lipid peroxidation in Caco-2 cells [36]. However, to our knowledge, the current study is the first to explore the genotoxicity of $\mathrm{Cr}(\mathrm{VI})$ in undifferentiated and differentiated Caco-2, a cell line highly relevant to the intestinal carcinogenicity of ingested $\mathrm{Cr}(\mathrm{VI})$.

Herein, we assess DNA damage in differentiated and undifferentiated Caco-2 cells following exposure to $\mathrm{Cr}(\mathrm{VI})$ using high content analysis, which is an imaging based multi-parametric approach to cell analysis at the single-cell level. Advantages of this method include: fully automated and unbiased image analysis, simultaneous analysis of multiple parameters in the same cell population, and high throughput capability [37,38]. Following treatment of Caco-2 with $\mathrm{Cr}(\mathrm{VI})$, DNA damage was monitored by the presence of phosphorylated histone variant H2AX $(\gamma-\mathrm{H} 2 \mathrm{AX})$ and 8-hydroxydeoxyguanosine $(8-\mathrm{OHdG})$ in the nucleus. 8Hydroxydeoxyguanosine is a marker of oxidative DNA damage, whereas H2AX phosphorylation is a sensitive indicator of DNA double strand breaks (DSB) and other forms of DNA damage that can arise from direct interaction between a chemical and DNA, ROS, replication stress, and DNA misrepair [39,40]. Additionally,
MN assays were conducted in Caco-2, CHO-K1, and A549 cell lines. Together, these studies can help inform the in vivo toxicity and carcinogenicity of $\mathrm{Cr}(\mathrm{VI})$ in the small intestine.

\section{Results}

\section{Cytotoxicity in Undifferentiated and Differentiated Caco-} 2

Cytotoxicity was assessed using Hoechst stain to identify cell number as well as determine nuclear size. Undifferentiated and differentiated Caco-2 cells were treated with $\mathrm{Cr}(\mathrm{VI})$ and two compounds known to alter cellular redox status and induce oxidative DNA damage, viz. hydrogen peroxide and rotenone. Treatment of undifferentiated Caco-2 cells with these compounds resulted in a dose-dependent reduction in cell numbers at $24 \mathrm{hr}$ post-treatment (Fig. 1A-C). In contrast, cell numbers of differentiated Caco-2 cells were less affected by treatment with the three compounds (Fig. 1D-F), indicating that differentiated cells were more resistant to chemical-induced cytotoxicity; only $100 \mu \mathrm{M} \mathrm{Cr}(\mathrm{VI})$ reduced cell number.

Nuclear area (or size) provides additional information on the health of cells. Increased nuclear area is often observed in compounds that block cell cycle and/or induce DNA damage $[41,42]$. Changes in nuclear area in differentiated and undifferentiated Caco-2 cells at 24-hr (Fig. 2) were in close agreement with changes in cell number at 24-hr (Fig. 1). In the undifferentiated Caco-2, nuclear area was significantly increased at $\geq 3 \mu \mathrm{M} \operatorname{Cr}(\mathrm{VI}), \geq 100 \mu \mathrm{M}$ peroxide, and in all rotenone concentrations $(\mathrm{p}<0.05$ by ANOVA followed by Dunnett's test). In differentiated Caco-2, nuclear area was significantly decreased at $100 \mu \mathrm{M} \mathrm{Gr}(\mathrm{VI})$ (Fig. 2B). The nuclear area of differentiated Caco-2 were smaller due, in part, to the difference in cell shape. Undifferentiated Caco-2 cells were flat and circular making nuclear measurements easier, whereas differentiated Caco-2 cells were columnar in shape and thus more difficult to measure the nucleus accurately. Nevertheless, differentiated cells treated with $100 \mu \mathrm{M} \mathrm{Cr}(\mathrm{VI})$ exhibited decreased nuclear size (Fig. 2B) and increased nuclear staining intensity (data not shown) compared to untreated cells. These findings suggest that the reduction in cell numbers in differentiated cells (Fig. 1D) might have been due to apoptosis. However, typical apoptosis markers p53 and annexin- $\mathrm{V}$ were not elevated as a result of $\mathrm{Cr}(\mathrm{VI})$ exposure (see below). Taken together, data in Figs. 1 and $\mathbf{2}$ indicate that differentiated intestinal cells were resistant to $\mathrm{Cr}(\mathrm{VI})$-induced cytotoxicity, and that treatment with $\leq 1 \mu \mathrm{M} \mathrm{Cr}(\mathrm{VI})$ did not induce obvious signs of cytotoxicity or cell cycle arrest in undifferentiated Caco-2 cells.

\section{Nuclear Staining of $\gamma-\mathrm{H} 2 \mathrm{AX}$ and $8-\mathrm{OHdG}$ in Undifferentiated Caco-2 Cells}

DNA damage in the form of 8-OHdG formation and H2AX phosphorylation were measured in Caco-2 cells at 2, 6 and $24 \mathrm{hrs}$ after treatment. Plots of nuclear staining intensity in undifferentiated Caco-2 cells are shown in Fig. 3 (concentrations to the right of the dashed lines are cytotoxic at $24 \mathrm{hr}$ ). At 2 hours post exposure, all three compounds increased $\gamma$-H2AX staining intensity at the highest concentrations without apparent increase in 8-OHdG staining intensity. By 6 hours, 8-OHdG staining in peroxide treated cells was elevated, although the data were not statistically significant. In contrast, $\gamma$-H2AX staining was significantly increased at $300 \mu \mathrm{M}$ peroxide. Rotenone treatment for 6 hours resulted in significant increases in both 8-OHdG and $\gamma$ $\mathrm{H} 2 \mathrm{AX}$ at 100 and $300 \mu \mathrm{M}$. Treatment with $\mathrm{Cr}(\mathrm{VI})$ for 6 hours increased 8-OHdG fluorescence, but only significantly at $30 \mu \mathrm{M}$. In contrast, $\gamma-\mathrm{H} 2 \mathrm{AX}$ staining was significantly increased at 
$\underline{\operatorname{Cr}(\mathrm{VI})}$
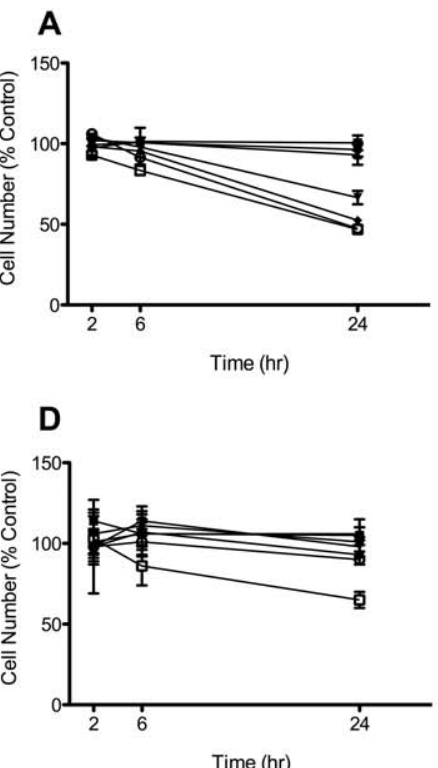

peroxide
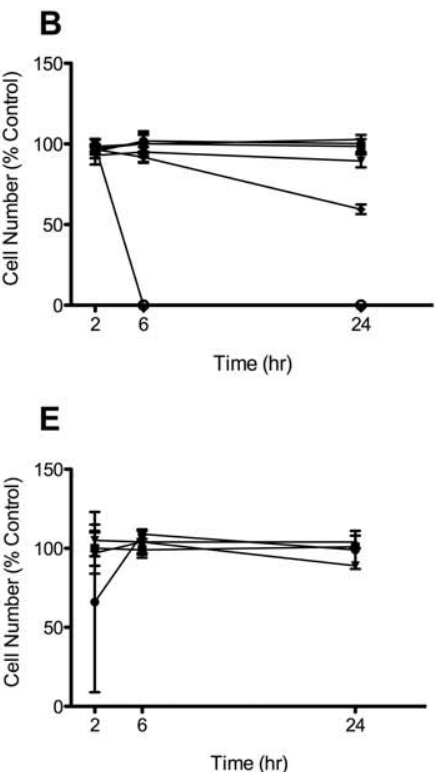

rotenone
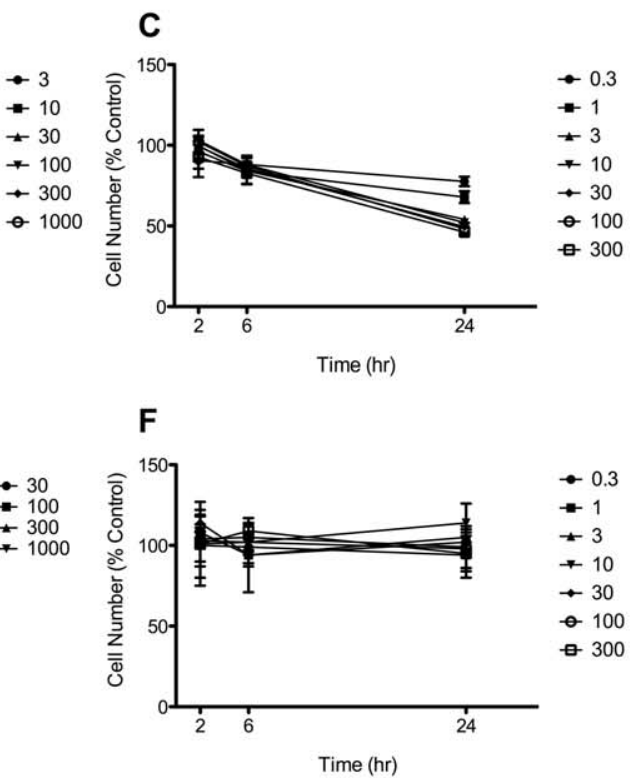

Figure 1. Cell viability in undifferentiated and differentiated Caco-2. Undifferentiated $(A-C)$ and differentiated (D-F) cells were treated with the indicated concentrations $(\mu \mathrm{M})$ of $\operatorname{Cr}(\mathrm{VI})(\mathrm{A}, \mathrm{D})$, hydrogen peroxide $(\mathrm{B}, \mathrm{E})$ or rotenone $(\mathrm{C}, \mathrm{F})$. Cell numbers were measured after 2, 6, and 24 hours of incubation. Data shown represents two independent experiments each in triplicate. Data are expressed as \% Control of vehicle-treated (water for hydrogen peroxide and $\mathrm{Cr}(\mathrm{VI})$, DMSO for rotenone) cells at same time point. Data are plotted as mean \pm s.d.

doi:10.1371/journal.pone.0042720.g001

$\geq 10 \mu \mathrm{M}$. Notably, there were no significant increases in $8-\mathrm{OHdG}$ or $\gamma-\mathrm{H} 2 \mathrm{AX}$ at non-cytotoxic concentrations for any of the compounds at 2-6 hours post exposure.

After 24-hour treatment at non-cytotoxic concentrations, all 3 compounds increased 8-OHdG staining. Only peroxide increased $\gamma$-H2AX staining at the highest non-cytotoxic concentration $(100 \mu \mathrm{M})$. In contrast, $\mathrm{Cr}(\mathrm{VI})$ and rotenone increased 8-OHdG staining without concomitant increases in $\gamma$-H2AX staining at non-cytotoxic concentrations. At cytotoxic concentrations, all 3 compounds significantly increased both $8-\mathrm{OHdG}$ and $\gamma$-H2AX nuclear staining intensity. Figure $\mathbf{4 A - F}$ shows representative images of 8-OHdG and $\gamma$-H2AX staining in control and $100 \mu \mathrm{M}$ $\mathrm{Cr}(\mathrm{VI})$ treated undifferentiated Caco-2 cells at $24 \mathrm{hr}$. As noted in other studies, 8-OHdG staining also occurs outside the nucleus due to the presence of RNA and mitochondrial DNA.

\section{Comparison of $\mathrm{EC}_{50}$ Values for $\gamma-\mathrm{H} 2 \mathrm{AX}$ and 8-OHdG in} Undifferentiated Caco-2 Cells

The half maximal effective concentration $\left(\mathbf{E C}_{50}\right)$ is the concentration of a toxicant which induces a response halfway between the base level and maximum after the exposure time. It is a commonly used measure of toxicant's potency. To compare the relative potency of the three compounds for $8-\mathrm{OHdG}$ and $\gamma$ $\mathrm{H} 2 \mathrm{AX}$ nuclear staining, $\mathrm{EG}_{50}$ values were derived from doseresponse modeling. For $\mathrm{Cr}(\mathrm{VI})$ and peroxide, the $\mathrm{EC}_{50}$ values for 8-OHdG were lower than $\gamma$-H2AX (Table 1; Fig. S1). Overall, these data indicate that $\mathrm{Cr}(\mathrm{VI})$, peroxide and rotenone increase oxidative DNA damage at lower concentrations than H2AX phosphorylation under longer term exposure (i.e. $24 \mathrm{hr}$ ), and that $\gamma$-H2AX formation was correlated with cytotoxicity - especially for $\mathrm{Cr}(\mathrm{VI})$ and rotenone.
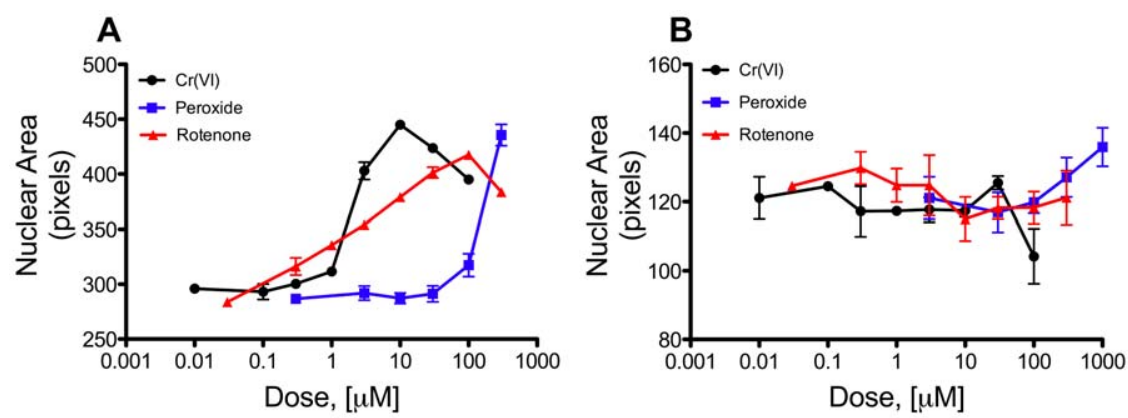

Figure 2. Nuclear morphology in undifferentiated and differentiated Caco-2. Nuclear area in undifferentiated (A) and differentiated (B) Caco-2. Nuclear area was measured in same cells as in Figure 1. Data shown represents two independent experiments, each in triplicate. Data are plotted as mean \pm SEM of nuclear area in actual pixels. Control values are plotted at 10-fold below the lowest treatment dose. doi:10.1371/journal.pone.0042720.g002 
$\underline{2 \mathrm{hr}}$
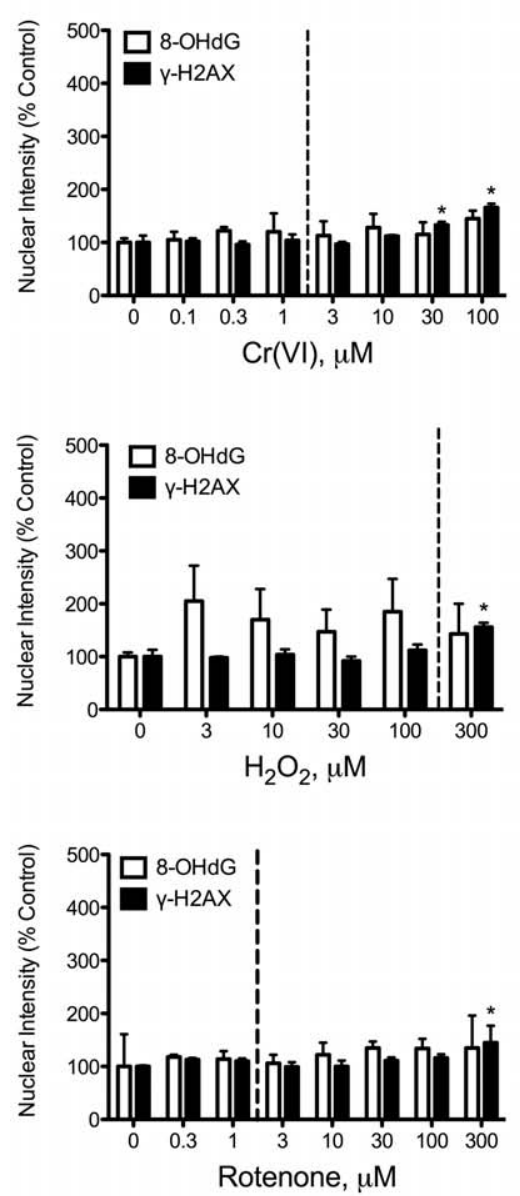

$6 \mathrm{hr}$
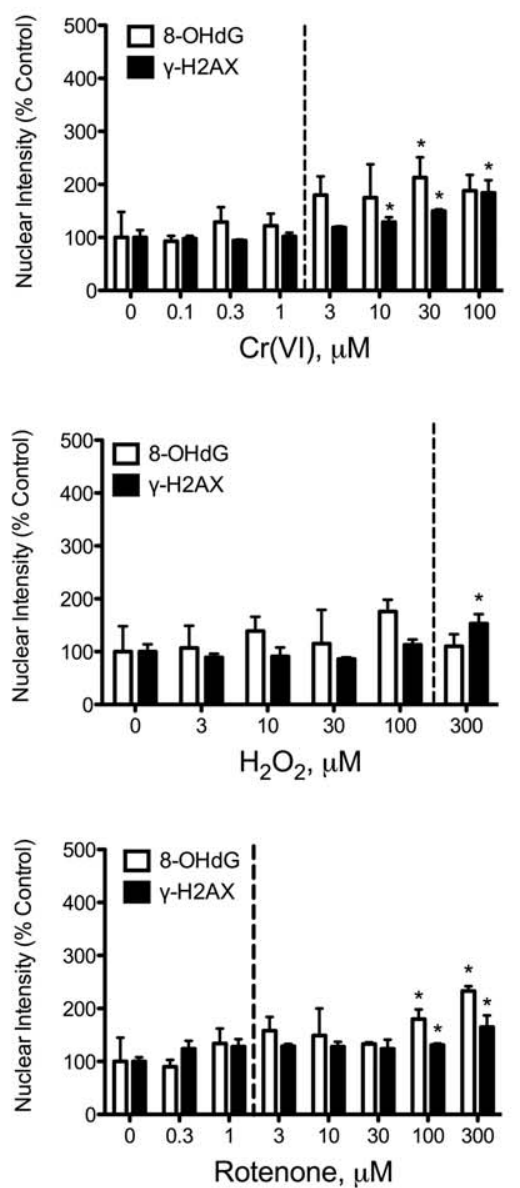

$24 \mathrm{hr}$
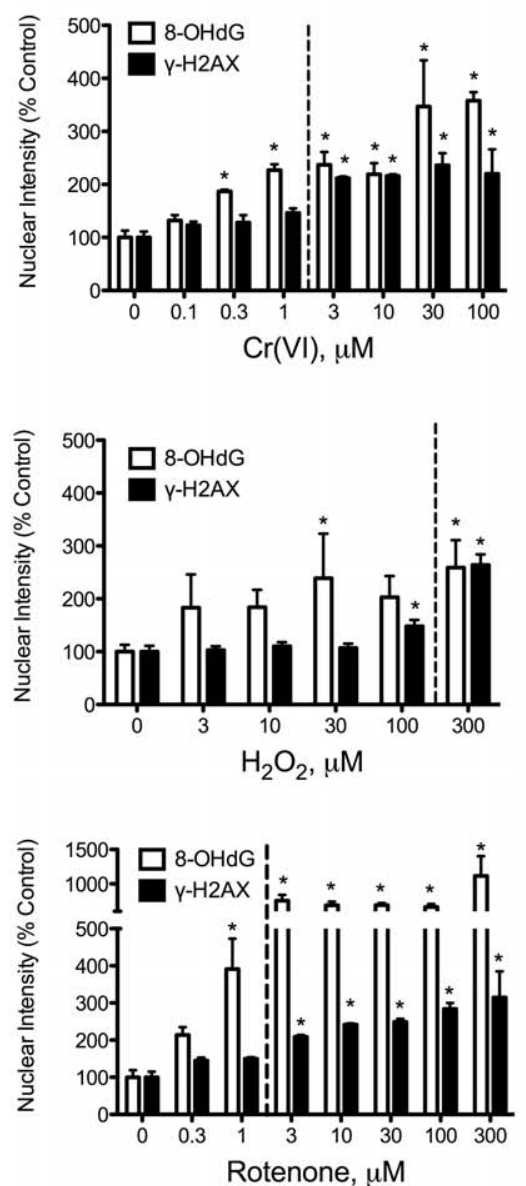

Figure 3. DNA damage in undifferentiated Caco-2. Nuclear staining intensity of $8-\mathrm{OHdG}$ and $\gamma-\mathrm{H} 2 \mathrm{AX}$ in undifferentiated Caco-2 cells. Cells were seeded at density $1 \times 10^{4}$ cells/100 $\mu \mathrm{l} /$ well, grown for $24 \mathrm{hr}$, then treated with the indicated concentrations of $\mathrm{Cr}(\mathrm{VI})$ (top), hydrogen peroxide (middle) or rotenone (bottom). Nuclear staining intensity was measured after 2, 6, and 24 hours of incubation. Concentrations to the right of the dotted line of each plot were cytotoxic (reduced cell numbers) at $24 \mathrm{hr}$ of exposure. Data are expressed as \% Control, and represent mean \pm s.d. ( $\mathrm{n}=3$, where $\mathrm{n}$ is number of individual replicates). ${ }^{*} \mathrm{p}<0.05$ by ANOVA followed by Dunnett's test.

doi:10.1371/journal.pone.0042720.g003
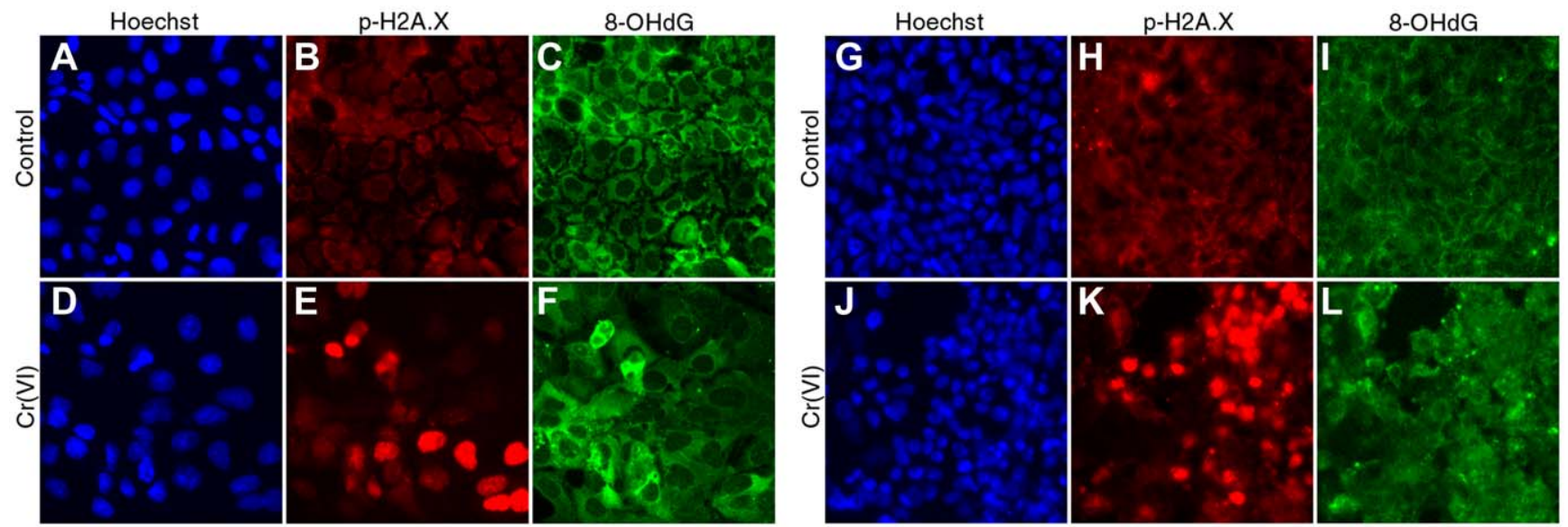

Figure 4. Representative images of 8-OHdG and $\gamma$-H2AX fluorescence in Caco-2. Representative images of 8-OHdG and $\gamma$ - $\mathrm{H} 2 \mathrm{AX}$ staining in control and $100 \mu \mathrm{M} \mathrm{Cr}(\mathrm{VI})$ treated undifferentiated $(\mathrm{A}-\mathrm{F})$ and differentiated $(\mathrm{G}-\mathrm{L})$ Caco-2 cells at $24 \mathrm{hr}$. All images were taken with the same magnification (20X). Intensity of 8-OHdG and $\gamma-\mathrm{H} 2 \mathrm{AX}$ immunostaining was determined in nuclear area identified by staining with Hoechst 33342. doi:10.1371/journal.pone.0042720.g004 
Table 1. $\mathrm{EC}_{50}$ values for $8-\mathrm{OHdG}$ and $\gamma-\mathrm{H} 2 \mathrm{AX}$ Nuclear Staining in Undifferentiated Caco-2.

\begin{tabular}{lll}
\hline & 8-OHdG $(\mu \mathbf{M})$ & $\gamma$-H2AX $(\mu \mathbf{M})$ \\
\hline $\operatorname{Cr}(\mathrm{VI})$ & 0.21 & 0.88 \\
Rotenone & 0.99 & 1.1 \\
Peroxide & 5.5 & 1.16 \\
\hline doi:10.1371/journal.pone.0042720.t001 &
\end{tabular}

Nuclear Staining of $\gamma-\mathrm{H} 2 \mathrm{AX}$ and 8-OHdG in Differentiated Caco-2 Cells

With the exception of $300 \mu \mathrm{M}$ peroxide, the 3 chemicals did not significantly alter $8-\mathrm{OHdG}$ or $\gamma-\mathrm{H} 2 \mathrm{AX}$ staining in differentiated Caco-2 cells after 2 to $6 \mathrm{hrs}$ of exposure (Fig. 5). After 24-hr treatment, peroxide increased 8-OHdG, albeit only significantly at $100 \mu \mathrm{M}$; in contrast, $\gamma$-H2AX staining was increased at $1 \mathrm{mM}$. Rotenone did not significantly increase $8-\mathrm{OHdG}$ or $\gamma$-H2AX staining at any treatment concentration. Exposure to $\mathrm{Cr}(\mathrm{VI})$ for 24 hours elicited increases in 8-OHdG at all concentrations, albeit only significantly at $0.3,30$ and $100 \mu \mathrm{M}$ (Fig. 5). Staining of $\gamma-$ H2AX was increased at 30 and $100 \mu \mathrm{M}$, although the latter concentration was cytotoxic (see Fig. 1D). In contrast to undifferentiated Caco-2 cells treated with $\mathrm{Cr}(\mathrm{VI}), 8-\mathrm{OHdG}$ and $\gamma-\mathrm{H} 2 \mathrm{AX}$ staining was more closely correlated in differentiated cells treated with $\mathrm{Gr}(\mathrm{VI})$. Fig. 4G-L shows representative images of 8OHdG and $\gamma$-H2AX staining in control and $100 \mu \mathrm{M} \mathrm{Cr}(\mathrm{VI})$ treated differentiated Caco-2 cells. This figure also shows the difference in cell density between proliferating and differentiated cells (Fig. 4A\&G), as well as disruption of the monolayer in differentiated Caco-2 cells treated with $100 \mu \mathrm{M} \mathrm{Gr}(\mathrm{VI})$ for $24 \mathrm{hr}$ (Fig. 4G\&J). Overall, these data indicate that differentiated Caco2 are less sensitive to $\mathrm{Cr}(\mathrm{VI})$ than undifferentiated Caco-2.

\section{Further Evaluation of Effects in Differentiated Caco-2 Cells}

In vivo studies indicate that damage to the intestinal villus is one of the earliest and most sensitive effects of $\mathrm{Cr}(\mathrm{VI})$ exposure $[2,20]$. In mice, $\mathrm{Gr}(\mathrm{VI})$ exposure results in changes in redox (viz. GSH/ GSSG ratio), villus cytoplasmic vacuolization, and karyorrhectic nuclei in the villus - whereas the intestinal crypts appear only to undergo proliferation in response to villus cytotoxicity [20]. To explore the effects of $\mathrm{Cr}(\mathrm{VI})$ on villus, we further stained differentiated Caco-2 cells with markers of apoptosis (p53 and annexin-V), autophagy (LC3B), and endoplasmic reticulum (ER) stress (ATF6). The latter was performed because toxicogenomic analyses indicated ER stress responses in the duodenum following Cr(VI) exposure [43].

Staining of differentiated Caco-2 cells with p53 and annexin-V resulted in no apparent changes in immunofluorescence at $24 \mathrm{hr}$ by any of the three compounds (data not shown). Similarly, there was no change in LCB3, which is normally present on autophagic vesicles. In contrast, there was a dose-dependent change in ATF6, a transcription factor that regulates the unfolded protein response (UPR). In unstressed conditions, ATF6 resides in the ER, but ER stress results in cleavage of ATF6 and translocation into the nucleus. As shown in Fig. 6A, $\mathrm{Cr}(\mathrm{VI})$ (and to a lesser extent rotenone) caused a dose dependent translocation of ATF6 from the cytoplasm to the nucleus. In untreated cells, ATF6 is located outside the nucleus and thus the mathematical difference in nuclear and cytoplasmic fluorescence is negative $(\mathbf{F i g} . \mathbf{6 A})$. This is evident in Fig. 6B where Hoechst nuclear fluorescence can be readily seen as blue staining, and ATF6 as red cytoplasmic staining. Treatment with $\mathrm{Cr}(\mathrm{VI})$ results in a decrease in cytoplasmic ATF6 fluorescence and an increase in nuclear ATF6 fluorescence, resulting in a positive value along the y-axis at higher $\operatorname{Cr}(\mathrm{VI})$ concentrations (Fig. 6A). This can be seen in Fig. 6C where the nuclear Hoechst fluorescence is obscured by ATF6 nuclear fluorescence. Notably, there was significant elevation in 8-OHdG and $\gamma-\mathrm{H} 2 \mathrm{AX}$ staining (Fig. 5 ) at concentrations where ATF6 was present in the nucleus. Together, these data suggest that $\mathrm{Cr}(\mathrm{VI})$ may induce an UPR in differentiated intestinal cells that is, in part, due to oxidative stress.

\section{Micronucleus Formation in CHO-K1 and A549 Cells}

For continuity with the previous assays, MN formation was assessed in Caco-2 cells; however, the background MN levels were not ideal, and it is recommended that only cells with very low background MN levels be used for testing [44]. Therefore, two alternative cells models were selected. $\mathrm{CHO}-\mathrm{K} 1$ cells were selected because they are a well-accepted in vitro cell model that is recommended by the Organisation for Economic Co-operation and Development (OECD) for assessing genotoxic potential via the $\mathrm{MN}$ assay [44]. Exposure to $\mathrm{Cr}(\mathrm{VI})$ reduced viability by $\sim 50 \%$ or more at $\geq 32 \mu \mathrm{M}$ (Table 2). The percentage of bi-nucleated cells was significantly reduced at $\geq 32 \mu \mathrm{M} \mathrm{Cr}(\mathrm{VI})$ - suggesting treatment-induced cell cycle arrest at $\geq 32 \mu \mathrm{M}$. At these cytotoxic and/or cytostatic concentrations $\mathrm{Cr}(\mathrm{VI})$ increased MN frequency (Table 2). In contrast, the clastogenic positive control MMC significantly $(p<0.001)$ increased MN frequency at concentrations that did not greatly reduce cell numbers or the percentage of binucleated cells (Table 2).

In addition to CHO-K 1 cells, the human lung adenocarcinoma epithelial A549 cell line was assessed for MN formation because $\mathrm{Cr}(\mathrm{VI})$ inhalation exposure is associated with increased risk of lung cancer. Treatment of A549 cells with $\mathrm{Cr}(\mathrm{VI})$ caused statistically significant $(p<0.001)$ increases in cytotoxicity and decreases in the percentage of bi-nucleated cells at $\geq 10 \mu \mathrm{M}$ (Table 3). $\mathrm{Cr}$ (VI) also caused relatively small but statistically significant $(\mathrm{p}<0.05)$ increases in cytotoxicity and decreases in the percentage of binucleated cells at $3.2 \mu \mathrm{M}$. At this concentration, the frequency of $\mathrm{MN}$ in bi-nucleated cells was slightly (but statistically significant; $\mathrm{p}<0.05$ ) increased from $1.47 \pm 0.50$ to $2.12 \pm 0.41 \%$ (Table 3). At higher concentrations the A549 cells were essentially dead. MMC significantly increased $(\mathrm{p}<0.001) \mathrm{MN}$ frequency from $1.47 \pm 0.50$ to $6.89 \pm 2.24 \%$ (Table 3 ). To explore whether this increase in MN frequency arose from clastogenic or aneugenic mechanisms, cells were stained with fluorescent antibodies for the kinetochore protein centromere protein-B (CENP-B). Treatment of A549 cells with MMC resulted in increases in kinetochore-negative MN (consistent with the clastogenic properties of MMC), whereas treatment with $\mathrm{Cr}(\mathrm{VI})$ did not alter the percentage of kinetochore negative MN (data not shown).

\section{Discussion}

The in vitro MN assay is a well-accepted test for assessing the genotoxic potential of a compound [44]. We employed CHO-K1 cells and HCA because the former is recommended by the OECD for in vitro genotoxicity testing [44], and because the latter allows for efficient screening of multiple fields of cells $(\sim 9000$ binucleated cells per treatment group) in an unbiased objective manner [45]. $\mathrm{Cr}(\mathrm{VI})$ did not significantly increase $\mathrm{MN}$ in $\mathrm{CHO}-$ $\mathrm{K} 1$, except at concentrations that decreased cell number and mitosis (bi-nucleated cells). Given these negative findings, we explored whether $\mathrm{Cr}(\mathrm{VI})$ could induce $\mathrm{MN}$ in A549 cells, which 
$2 \mathrm{hr}$
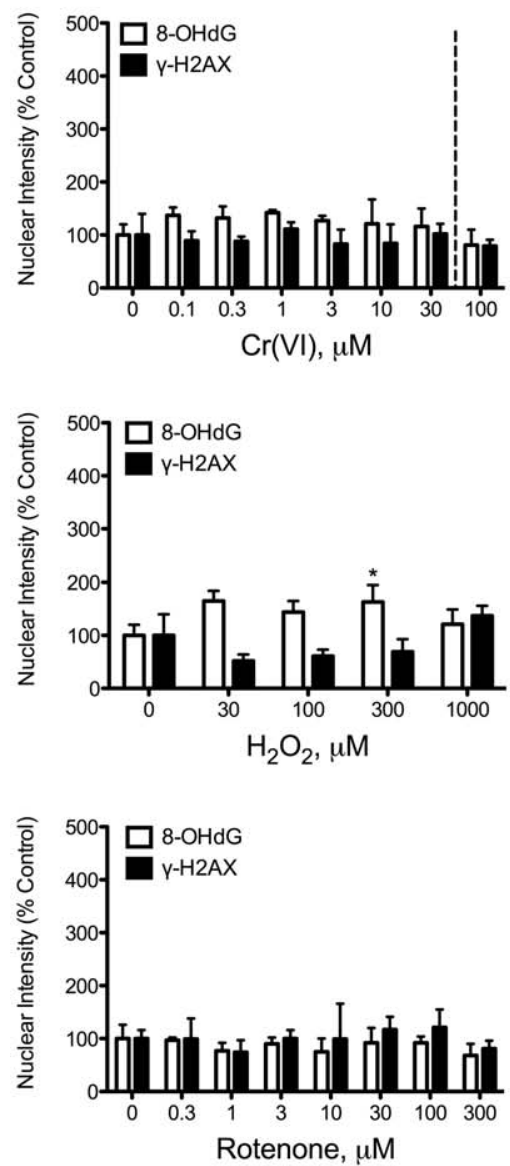

$\underline{6 \mathrm{hr}}$
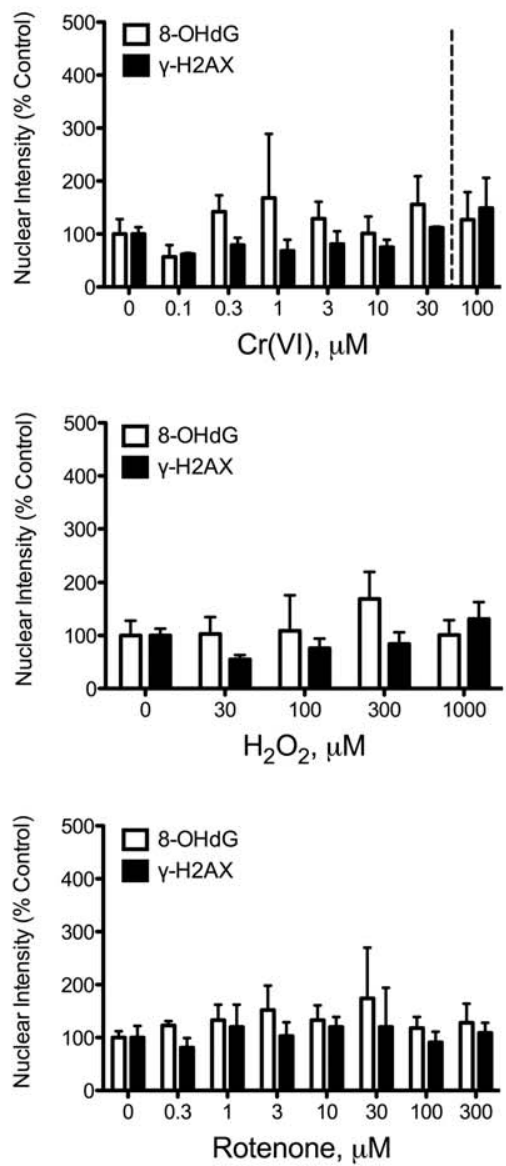

$24 \mathrm{hr}$
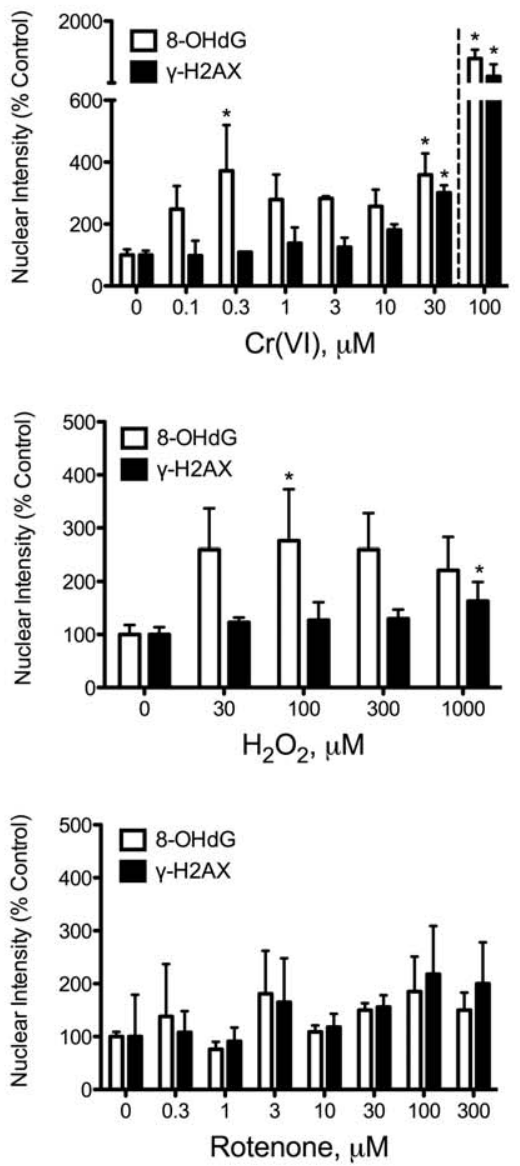

Figure 5. DNA damage in differentiated Caco-2. Nuclear staining intensity of 8-OHdG and $\gamma-\mathrm{H} 2 \mathrm{AX}$ in differentiated Caco-2 cells. Cells were seeded at density $2 \times 10^{4}$ cells/100 $\mu \mathrm{l} /$ well in Collagen I coated plates, grown for 21 days, then treated with the indicated concentrations of $\mathrm{Cr}(\mathrm{VI})$ (top), hydrogen peroxide (middle) or rotenone (bottom). Nuclear staining intensity was measured after 2, 6, and 24 hours of incubation. Concentrations to the right of the dotted line of each plot were cytotoxic (reduced cell numbers) at $24 \mathrm{hr}$ of exposure. Data are expressed as \% Control, and represent mean \pm s.d. ( $n=3$, where $n$ is number of individual replicates). ${ }^{*} p<0.05$ by ANOVA followed by Dunnett's test. doi:10.1371/journal.pone.0042720.g005

A

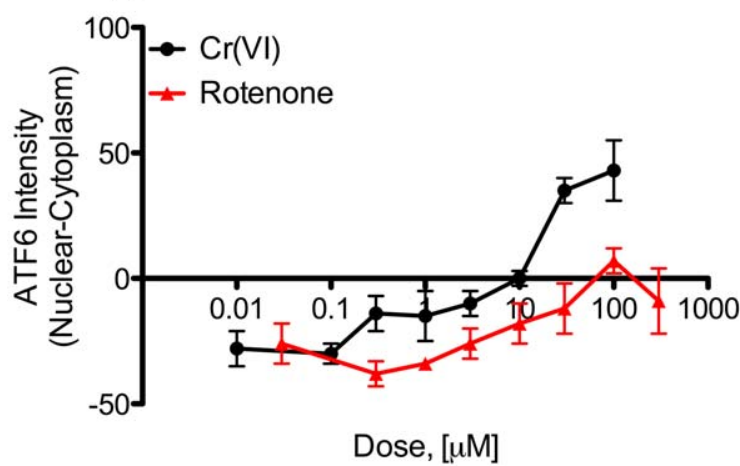

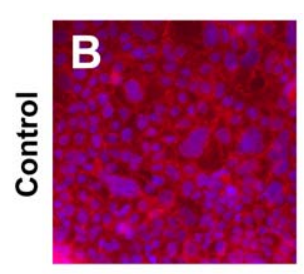

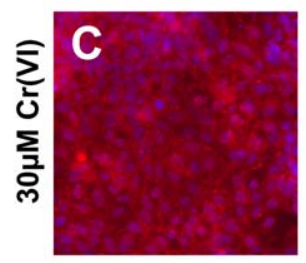

Figure 6. ATF6 localization in differentiated Caco-2. (A) Difference between nuclear and cytoplasmic expression of ATF6. Positive slope indicates translocation of ATF6 into the nucleus. (B) Dual channel overlay of Hoechst (blue) and ATF6 (red) fluorescence in untreated Caco-2 cells. Blue nuclei indicate relative absence of ATF6 in nucleus. (C) Dual channel overlay of Hoechst and ATF6 fluorescence in Caco-2 treated with $30 \mu \mathrm{M} \mathrm{Cr}(\mathrm{VI})$ for $24 \mathrm{hr}$. Loss of blue nuclei indicate movement of ATF6 into the nucleus. Data are plotted as mean $\pm s . d$. $(n=3$, where $n$ is number of individual replicas).

doi:10.1371/journal.pone.0042720.g006 
Table 2. Micronuclei Formation in CHO-K1 Cells.

\begin{tabular}{|c|c|c|c|c|c|c|c|c|c|}
\hline \multirow[b]{2}{*}{ Control } & \multicolumn{3}{|c|}{ Cell Count (\%Control) } & \multicolumn{3}{|c|}{$\%$ Binucleated } & \multicolumn{3}{|c|}{$\%$ Micronuclei $^{\mathrm{a}}$} \\
\hline & 99.94 & \pm & 6.66 & 68.99 & \pm & 2.58 & 1.41 & \pm & 0.68 \\
\hline \multicolumn{10}{|c|}{ MMC $(\mu \mathrm{M})$} \\
\hline 1 & 98.56 & \pm & 6.39 & 70.22 & \pm & 1.56 & 1.69 & \pm & 0.90 \\
\hline 10 & 101.70 & \pm & 5.81 & 69.33 & \pm & 2.40 & 1.86 & \pm & 0.90 \\
\hline 100 & 91.11 & \pm & $7.46^{\mathrm{b}}$ & 62.33 & \pm & $1.94^{\mathrm{b}}$ & 4.14 & \pm & $1.85^{\mathrm{b}}$ \\
\hline \multicolumn{10}{|c|}{$\mathrm{Cr}(\mathrm{VI})(\mu \mathrm{M})$} \\
\hline 0.1 & 99.67 & \pm & 4.56 & 71.44 & \pm & 1.24 & 1.32 & \pm & 0.80 \\
\hline 0.3 & 111.60 & \pm & 12.64 & 71.11 & \pm & 2.15 & 1.51 & \pm & 0.77 \\
\hline 1 & 108.00 & \pm & 10.55 & 70.22 & \pm & 2.22 & 1.71 & \pm & 0.86 \\
\hline 3.2 & 98.89 & \pm & 7.25 & 69.44 & \pm & 1.94 & 1.79 & \pm & 1.06 \\
\hline 10 & 81.33 & \pm & $4.27^{\mathrm{b}}$ & 62.78 & \pm & 2.17 & 1.70 & \pm & 1.15 \\
\hline 32 & 55.11 & \pm & $5.04^{b}$ & 12.00 & \pm & $1.00^{\mathrm{b}}$ & 3.96 & \pm & 4.03 \\
\hline 100 & 19.89 & \pm & $1.27^{\mathrm{b}}$ & 15.22 & \pm & $1.39^{\mathrm{b}}$ & 5.86 & \pm & 7.16 \\
\hline
\end{tabular}

$\mathrm{a}_{\%}$ micronuclei in binucleated cells.

${ }^{b}$ statistically significant by ANOVA followed by Dunn's post hoc test $(p<0.05)$.

data are mean $\pm S D$.

doi:10.1371/journal.pone.0042720.t002

are of potential relevance due to associations between inhaled $\mathrm{Cr}(\mathrm{VI})$ exposure and lung cancer. In these cells, $\mathrm{Cr}(\mathrm{VI})$ increased MN frequency slightly, but again only at concentrations that also decreased the number of bi-nucleated cells. Together, the findings from these two cell lines suggest that $\mathrm{Cr}(\mathrm{VI})$ is only weakly genotoxic.

Other studies have reported increases in MN frequency in cells that are first pretreated with $\mathrm{mM}$ concentrations of dehydroascorbic acid (DHA) in order to elevate cellular ascorbate to levels reported in tissues and freshly isolated cells [46,47]. However, ascorbate is known to interact with culture media constituents and generate peroxide, which can potentiate the genotoxicity of other compounds $[48,49,50,51,52]$. It is also known that DHA reduction to ascorbate is mediated nonenzymatically by GSH as well as enzymatically through GSH-dependent and NADPH-dependent reactions [53,54]; thus loading cells with ascorbate may alter cellular redox and, contrary to some arguments [46], may not accurately recapitulate in vivo tissue conditions.

Despite the weak evidence for genotoxicity in the MN assay, $\mathrm{Cr}(\mathrm{VI})$ is well documented to induce DNA lesions, including CrDNA adducts, DNA-protein crosslinks, DNA-Cr-DNA crosslinks, and oxidative DNA damage (see recent reviews on $\mathrm{Cr}(\mathrm{VI})$ carcinogenicity $[8,9,10,12])$. Because chronic ingestion of $\mathrm{Cr}(\mathrm{VI})$ has been shown to cause intestinal tumors in the mouse small intestine [2], Caco-2 cells were used as an in vitro intestinal model to study the potential for $\mathrm{Cr}(\mathrm{VI})$ to induce DNA damage in the

Table 3. Micronuclei Formation in A549 Cells.

\begin{tabular}{|c|c|c|c|c|c|c|c|c|c|}
\hline \multirow[b]{2}{*}{ Control } & \multicolumn{3}{|c|}{ Cell Count (\%Control) } & \multicolumn{3}{|c|}{$\%$ Binucleated } & \multicolumn{3}{|c|}{$\%$ Micronuclei $^{\mathrm{a}}$} \\
\hline & 99.94 & \pm & 8.113 & 59.62 & \pm & 5.78 & 1.47 & \pm & 0.50 \\
\hline \multicolumn{10}{|c|}{ MMC $(\mu \mathrm{M})$} \\
\hline 1 & 98.78 & \pm & 3.80 & 58.78 & \pm & 3.35 & 1.41 & \pm & 0.37 \\
\hline 10 & 95.22 & \pm & 3.31 & 57.00 & \pm & 2.78 & 1.70 & \pm & 0.27 \\
\hline 100 & 78.78 & \pm & $5.52^{\mathrm{b}}$ & 46.78 & \pm & $3.07^{\mathrm{b}}$ & 6.89 & \pm & $2.24^{\mathrm{b}}$ \\
\hline \multicolumn{10}{|c|}{$\operatorname{Cr}(\mathrm{VI})(\mu \mathrm{M})$} \\
\hline 0.1 & 98.44 & \pm & 5.62 & 58.56 & \pm & 2.35 & 1.51 & \pm & 0.35 \\
\hline 0.3 & 94.33 & \pm & 5.43 & 56.00 & \pm & 1.94 & 1.62 & \pm & 0.45 \\
\hline 1 & 93.11 & \pm & 5.80 & 55.33 & \pm & 2.40 & 1.46 & \pm & 0.33 \\
\hline 3.2 & 87.00 & \pm & $4.30^{\mathrm{b}}$ & 51.67 & \pm & $1.80^{\mathrm{b}}$ & 2.12 & \pm & $0.41^{c}$ \\
\hline 10 & 33.33 & \pm & $2.12^{\mathrm{b}}$ & 20.00 & \pm & $1.32^{\mathrm{b}}$ & 2.12 & \pm & $0.81^{c}$ \\
\hline 32 & 19.22 & \pm & $2.11^{\mathrm{b}}$ & 11.33 & \pm & $1.23^{\mathrm{b}}$ & 0.00 & \pm & $0.00^{\mathrm{b}}$ \\
\hline 100 & 25.78 & \pm & $1.99^{\mathrm{b}}$ & 15.33 & \pm & $1.41^{\mathrm{b}}$ & 0.00 & \pm & $0.00^{\mathrm{b}}$ \\
\hline
\end{tabular}

${ }^{\mathrm{a}} \%$ micronuclei in binucleated cells.

${ }^{b}$ statistically significant by ANOVA followed by Dunn's post hoc test $(p<0.05)$.

'statistically significant by ANOVA followed by Dunnett's post hoc test $(p<0.05)$.

data are mean \pm SD.

doi:10.1371/journal.pone.0042720.t003 
small intestine. In short-term culture, Caco-2 cells are undifferentiated and proliferate, and thus share some characteristics with intestinal crypt enterocytes. When grown for $\sim 21$ days, Caco-2 differentiate and develop morphological characteristics of mature villus enterocytes. Thus, undifferentiated and differentiated Caco-2 cells recapitulate intestinal enterocytes along the cryptvillus axis, respectively.

A major finding from this study was that differentiated Caco-2 cells were more resistant to $\mathrm{Cr}(\mathrm{VI})$, peroxide, and rotenone than undifferentiated/proliferating Caco-2 cells. Neither rotenone nor peroxide induced cytotoxicity in differentiated cells, and the cytotoxicity of $\mathrm{Cr}(\mathrm{VI})$ was greatly diminished. In contrast, all three compounds reduced the number of undifferentiated Caco-2 cells in a concentration and time-dependent manner. $\mathrm{Cr}(\mathrm{VI})$ treatment increased both $8-\mathrm{OHdG}$ and $\gamma$-H2AX nuclear staining at concentrations that reduced cell numbers and increased nuclear size, suggesting that DNA damage was associated with cytotoxicity and/or cell cycle arrest. Findings with respect to greater H2AX phosphorylation in proliferating but not differentiated Caco-2 cells treated with $\mathrm{Cr}(\mathrm{VI})$ are consistent with previous reports indicating that $\mathrm{Cr}(\mathrm{VI})$ primarily induced $\gamma-\mathrm{H} 2 \mathrm{AX}$ nuclear staining in normal human fibroblasts in S-phase, in part due to replication stress [55]. Although GSH levels may be higher in undifferentiated than differentiated Caco-2 cells [56], oxidative DNA damage appeared to be greater in undifferentiated cells. Similar patterns of differentiation-dependent disparities in oxidative DNA damage in response to oxidants have been observed in other cells types [57]. Notably, cellular protein content is several-fold higher in differentiated than undifferentiated Caco-2 cells [56], and thus increases in antioxidant enzymes and DNA repair enzymes might partially explain the recalcitrance of differentiated Caco-2 cells. However, it is also conceivable that the higher GSH in undifferentiated Caco-2, by reducing $\mathrm{Cr}(\mathrm{VI})$ to $\mathrm{Cr}(\mathrm{III})$ and thereby generating reactive intermediates, paradoxically potentiated oxidative DNA damage in these cells.

Another major finding from this Caco-2 model is that $\mathrm{Cr}(\mathrm{VI})$ increased 8-OHdG staining at lower concentrations than $\gamma$-H2AX staining as evidenced by their respective $\mathrm{EG}_{50}$ values. The $\mathrm{EG}_{50}$ for 8-OHdG staining was approximately 4 -fold lower than for $\gamma$ H2AX staining $(0.21$ vs. $0.88 \mu \mathrm{M})$. The mechanism of $\mathrm{Cr}(\mathrm{VI})$ induced 8-OHdG formation is not clear. Previous studies have shown that $\mathrm{Cr}(\mathrm{VI})$-induced toxicity in A549 cells could be ameliorated by catalase, suggesting involvement of peroxide formation [58]. Although peroxide treatment was far less potent than $\mathrm{Cr}(\mathrm{VI})$ in inducing $8-\mathrm{OHdG}$ nuclear staining, $\mathrm{Cr}(\mathrm{VI})$ reduction involves binding to antioxidants such as GSH, formation of unstable reactive chromium intermediates such as $\mathrm{Cr}(\mathrm{V})$, and generation of ROS (e.g. peroxide) - and is therefore likely to affect cells differently than peroxide alone. Interestingly, several studies have reported that continuous passage (4-24 weeks) of human bronchial epithelial Beas-2B cells in $0.25-5 \mu \mathrm{M} \mathrm{Cr}(\mathrm{VI})$ can cause transformation $[13,14,15]$. Based on data herein, $0.25-5 \mu \mathrm{M}$ $\mathrm{Cr}(\mathrm{VI})$ may be high enough to increase 8-OHdG formation that could eventually lead to DNA damage, mutation and transformation. Indeed, Wang et al. (2011) showed that $2 \mu \mathrm{M} \mathrm{Cr}(\mathrm{VI})$ increased ROS in Beas-2B cells, and that transformation of Beas2B cells during chronic exposure to $0.25 \mu \mathrm{M} \quad \mathrm{Cr}(\mathrm{VI})$ was ameliorated by transfection of plasmids containing superoxide dismutase, catalase, or RNA inhibitors of NADPH oxidase (NOX) [15]. Certain NOX family members and the related dual oxidases are highly expressed in Caco-2 cells and throughout the gastrointestinal tract $[59,60]$, and their propensity to generate superoxide might play a role in $\operatorname{Cr}(\mathrm{VI})$ cytotoxicity and carcinogenicity in the small intestine. Notably, macrophages express NOX enzymes and $\mathrm{Cr}(\mathrm{VI})$ exposure was accompanied by infiltration of macrophages into the intestine $[2,17,20,61]$.

H2AX phosphorylation is a sensitive indicator of DNA DSB, which can results from chemical-induced DNA damage or damage introduced as a result of DNA repair $[39,40]$. It is suggested that Cr-DNA binary adducts may represent more than $75 \%$ of all CrDNA adducts (binary and ternary combined), and that these binary adducts have relatively weak mutagenic potential [12]. Repair of these adducts is mediated primarily by nucleotide excision repair (NER) pathways [12], but it has been shown that the number of mutations in $\operatorname{Cr}(\mathrm{VI})$-treated cells is lower in cells deficient in NER as well as base excision repair (BER) [62] suggesting that much of $\mathrm{Cr}(\mathrm{VI})$-induced DNA mutations occur as a result of DNA misrepair. Ternary Cr-DNA adducts (e.g. GSHCr-DNA) are less common but may be more mutagenic, as these lesions can lead to DNA DSB formation and replication inhibition/stress [10,11,12,55]. Replication inhibition induces mismatch repair (MMR) processes that can introduce DNA DSB and H2AX phosphorylation $[12,39,55,63]$. Thus, the repair of Cr-DNA adducts by NER, BER and MMR can all result in DNA DSB and H2AX phosphorylation [39]. In addition to CrDNA adducts, ROS from $\mathrm{Cr}(\mathrm{VI})$ reduction to intermediate valences as well as changes in cellular redox status can generate single and double strand breaks that result in H2AX phosphorylation [39,40,64]. Clearly then, the $\mathrm{Cr}(\mathrm{VI})$-induced H2AX phosphorylation described herein cannot be attributed to any single type of lesion. Importantly, it has been suggested that H2AX phosphorylation serves as a general indicator of cellular stress, DNA damage, and genomic integrity [39]; thus the absence of $\gamma$ H2AX staining below $3 \mu \mathrm{M} \mathrm{Cr}(\mathrm{VI})$ may suggest that the 8-OHdG is not indicative of severe DNA damage. In support of this, increases in $\gamma-\mathrm{H} 2 \mathrm{AX}$ at $\geq 3 \mu \mathrm{M} \mathrm{Cr}(\mathrm{VI})$ corresponded to increases in nuclear area - which may be indicative of cell cycle arrest due to the presence of DNA DSB. Although we cannot rule out the possibility that low levels of adducts or damage occurred and were either efficiently repaired or insufficient to increase $\gamma$-H2AX staining, phosphorylation of $\mathrm{H} 2 \mathrm{AX}$ is reported to be orders of magnitude more sensitive than other methods of DNA DSB detection [39]. Nevertheless, future analyses using additional markers of DNA damage (e.g. TUNEL staining or Comet assay) as well as assessment of Cr-DNA binding could further inform the genotoxicity of $\mathrm{Cr}(\mathrm{VI})$ in Caco-2.

The Caco-2 model described herein may provide additional insight into in vivo mechanistic studies recently published on the effects of $\mathrm{Cr}(\mathrm{VI})$ on the rodent small intestine [20,26,27]. In these studies, mice were exposed for 90 days to $0.1-182 \mathrm{mg} / \mathrm{L} \mathrm{Cr}(\mathrm{VI})$, or approximately $2-3,000 \mu \mathrm{M} \mathrm{Cr}(\mathrm{VI})$ [20]. Although $\mathrm{Cr}(\mathrm{VI})$ is reduced to $\mathrm{Cr}$ (III) in gastric fluid [65], it is likely that much of the $\mathrm{Cr}(\mathrm{VI})$ is not reduced at the higher treatment concentrations as evidenced by tissue chromium levels [20]. Despite the presence of $\mathrm{Cr}(\mathrm{VI})$ in the lumen, toxicity was confined to the villus, which was accompanied by hyperplasia in the crypt [20]. Analysis of duodenal crypts indicated no increases in apoptotic index or aberrant nuclei (e.g. MN) after 7 or 90 days of exposure to $\mathrm{Cr}(\mathrm{VI})$ in drinking water [26]. Moreover, changes in $K$-ras mutation frequency, an early mutation often found in intestinal adenomas [66], were not detected in scraped duodenal mucosa cells (including crypts) after 90 days of exposure [27]. In contrast to these in vivo data indicating an apparent absence of toxicity in intestinal crypts, undifferentiated/proliferating Caco-2 cells were far more sensitive to $\mathrm{Cr}(\mathrm{VI})$-induced toxicity than differentiated Caco-2, and exhibited no $\mathrm{Cr}(\mathrm{VI})$-induced increase in proliferation. These disparate responses between undifferentiated Caco-2 and intestinal crypt cells suggest that the latter were not directly 
exposed to $\mathrm{Cr}(\mathrm{VI})$ in vivo, and that crypt hyperplasia was likely due to toxicity in the villus. However, it cannot be ruled out that oxidative species either from the lumen or surrounding cells (e.g. macrophages), together with proliferative pressure, contributed to intestinal carcinogenesis in mice. A similar villus injury/crypt hyperplasia mechanism has been proposed for the pesticides captan and folpet - which, like $\operatorname{Cr}(\mathrm{VI})$, react with thiols, induce duodenal villus toxicity, crypt hyperplasia and intestinal tumors in mice but not rats $[67,68]$.

The affect of $\mathrm{Cr}(\mathrm{VI})$ on ATF6 translocation to the nucleus in differentiated Caco-2 cells is consistent with toxicogenomic responses following $\mathrm{Cr}(\mathrm{VI})$ exposure, viz. activation of ER stress transcription factors ATF4 and XBP1 in the duodenum [43]. ATF6, ATF4, and XBP1 are involved in ER stress response, and ATF4 plays an important role in the regulation of autophagy, which is characterized by autophagosomal vacuoles in the cytoplasm [69]. These in vitro and in vivo findings further suggest that the toxicity in villi is related to oxidative stress. The lack of $\mathrm{Cr}(\mathrm{VI})$-induced activity of p53 and Annexin V in differentiated Caco-2 cells is consistent with the absence of apoptosis in villus enterocytes (although $\mathrm{Cr}(\mathrm{VI})$ did induce apoptosis in other cells of the villous lamina propria) [20].

In summary, proliferating/undifferentiated Caco-2 cells were more sensitive to $\mathrm{Cr}(\mathrm{VI})$ than differentiated Caco-2 cells, and oxidative DNA damage was detected at lower concentrations than H2AX phosphorylation. The findings suggest that in vitro studies showing the transformation of cells following long-term culture with low $\mu \mathrm{M} \mathrm{Cr}(\mathrm{VI})$ concentrations may be due to prolonged increases in oxidative stress. The findings also suggest that in vivo studies indicating villus but not crypt toxicity following ingestion of $\mathrm{Cr}(\mathrm{VI})$ in drinking water imply that crypt cells were not in direct contact with $\mathrm{Cr}(\mathrm{VI})$. Additional investigations are underway to further explore toxicity and carcinogenicity of $\mathrm{Cr}(\mathrm{VI})$ in the small intestine.

\section{Materials and Methods}

\section{Cell Culture}

Caco-2 cells (ATCG HTB-37) were maintained and seeded in RPMI-1640 medium (Thermo Fisher Scientific) containing 20\% FBS (Thermo Fisher Scientific), $2 \mathrm{mM}$ L-Glutamine (Thermo Fisher Scientific), $1 \mathrm{mM}$ sodium pyruvate (Thermo Fisher Scientific), 1X non-essential amino acids (Thermo Fisher Scientific), $100 \mathrm{U} / \mathrm{ml}$ penicillin and $100 \mu \mathrm{g} / \mathrm{ml}$ streptomycin (Thermo Fisher Scientific). CHO-K1 cells (ATCG, CGL-61) were maintained and seeded in F12-K medium (Thermo Fisher Scientific) containing 10\% FBS (Thermo Fisher Scientific), $100 \mathrm{U} / \mathrm{ml}$ penicillin and $100 \mu \mathrm{g} / \mathrm{ml}$ streptomycin (Thermo Fisher Scientific). A549 cells (ATCG, CGL-185) were maintained and seeded in F12-K medium (Thermo Fisher Scientific) containing 10\% FBS (Thermo Fisher Scientific), $2 \mathrm{mM}$ L-Glutamine (Thermo Fisher Scientific), $1 \mathrm{mM}$ sodium pyruvate (Thermo Fisher Scientific), $100 \mathrm{U} / \mathrm{ml}$ penicillin and $100 \mu \mathrm{g} / \mathrm{ml}$ streptomycin (Thermo Fisher Scientific).

For assays in undifferentiated/proliferating Caco-2 cells, cells were seeded at a density of $1 \times 10^{4}$ cells/ $100 \mu \mathrm{l} /$ well in Nunc Edge 96-well microplates (Thermo Fisher Scientific) $24 \mathrm{hr}$ prior to incubation with compounds. For assays in differentiated Caco-2 monolayers, cells were seeded at a density of $2 \times 10^{4}$ cells $/ 100 \mu \mathrm{l} /$ well in Collagen I (BD Biosciences) coated Nunc Edge 96-well microplates (Thermo Fisher Scientific), and cultured for 21 days prior to incubation with compounds, with a media change every other day. Test compounds include: $\mathrm{Cr}(\mathrm{VI})$ in the form of sodium dichromate dihydrate (SDD) $(0.1-100 \mu \mathrm{M})$, hydrogen peroxide
(3-1000 $\mu \mathrm{M})$, and rotenone $(0.3-300 \mu \mathrm{M})$ (all from Sigma). Stock solutions of SDD and hydrogen peroxide were prepared in $\mathrm{H}_{2} \mathrm{O}$. Rotenone was prepared in DMSO at a final concentration of $0.25 \%$ DMSO. Cells were incubated with all compounds for $2 \mathrm{hr}$, $6 \mathrm{hr}$, and $24 \mathrm{hr}$.

\section{Immunocytochemistry}

After incubation cells were fixed with $4 \%$ paraformaldehyde in PBS (EMS). Harvested cells were incubated with $0.05 \mathrm{M} \mathrm{NaOH}$ in $40 \%$ ethanol for $12 \mathrm{~min}$ and $250 \mu \mathrm{g} / \mathrm{ml} \mathrm{RNAse}$ A for $60 \mathrm{~min}$ at $37^{\circ} \mathrm{C}$ as previously described [70]. For immunocytochemistry, plates were incubated in $1 \mathrm{X}$ blocking buffer (Thermo Fisher Scientific) for one hour prior to addition of primary and secondary antibody (each incubated for $1 \mathrm{hr}$ at room temperature). Primary antibodies: mouse monoclonal 8-Hydroxyguanosine antibody (Abcam ab62623), rabbit polyclonal gamma H2A.X (phospho S139) antibody (Abcam ab2893), mouse monoclonal p53(Abcam ab1101), mouse monoclonal ATF6 (Abcam ab11909), rabbit polyclonal LC3B (Abcam ab63817), rabbit polyclonal Annexin V (Abcam ab14196). Secondary antibodies: Alexa Fluor 488 goat anti-mouse $\operatorname{IgG}(\mathrm{H}+\mathrm{L})$ (Invitrogen A-11001), Alexa Fluor 647 goat anti-rabbit IgG (H+L) (Invitrogen A-21244). Hoechst 33342 was used as a nuclear counterstain for automated cell identification. This counterstain was also used to determine nuclear size (image area) and nuclear staining intensity. Plates were imaged using the Thermo Scientific ArrayScan VTI HCS Reader (Thermo Fisher Scientific) and analyzed using the Compartmental Analysis BioApplication (Thermo Fisher Scientific). Immunostaining-based parameters and nuclear staining based parameters were determined and analyzed in the same image set for each field. No less then 3 fields (>500 cells) where analyzed for each data replicate.

\section{Micronucleus Assay}

The CHO-K1 and A549 micronucleus assays were performed according to the Cellomics Micronucleus Kit (Thermo Fisher Scientific) instructions. CHO-K1 cells were seeded at a density of $3 \times 10^{3}$ cells per $100 \mu \mathrm{l} /$ well $18 \mathrm{hrs}$ prior to chemical treatment. A549 cells were seeded at $5 \times 10^{3}$ cells per $100 \mu \mathrm{l} /$ well $18 \mathrm{hrs}$ prior to chemical treatment. Both CHO-K1 and A549 cells were treated for $20 \mathrm{hr}$ with $\mathrm{Cr}(\mathrm{VI})$ in the form of SDD (Sigma), and mitomycin G (MMC; Tocris). Cells were treated with $6 \mu \mathrm{g} / \mathrm{ml}$ Cytochalasin $\mathrm{B}$ following compound treatment and incubated for a further 27.5 hours. Micronucleus assay in Caco-2 cells was performed as previously described [71]. The fraction of $\mathrm{MN}$ with centromeric chromatin was determined in A549 cells by immunofluorescent staining using anti-kinetochore antibodies targeting CENPB (Abcam ab25734). Cells were co-stained with Hoechst 33342 and SYTO Red (Life Technologies) nucleic acid stains to reveal nuclei, micronuclei and cell bodies. For all cell lines, plates were imaged using ArrayScan VTI (Thermo Fisher Scientific). No less than one thousand cells or 40 fields (20X) were acquired and analyzed for each well. All images were analyzed using the Micronucleus BioApplication (Thermo Fisher Scientific).

\section{Statistics}

All data were analyzed by one-way ANOVA followed by Dunnett's or Dunn's post hoc tests using Prism 5 for Mac OS X (GraphPad Software, Inc.). For $\mathrm{EC}_{50}$ derivation, data were normalized and modeled using nonlinear regression in Prism 5 for Mac OS X. 


\section{Supporting Information}

Figure S1 Modeling of nuclear staining intensity in proliferating Caco-2 cells at $24 \mathrm{hr}$. Concentrations shown include up to first two toxic concentrations.

(TIF)

\section{References}

1. IARC (1990) Chromium, nickel and welding, IARC Monogr. Eval. Carcinog. Risks Hum. 49: 1-648.

2. NTP (2008) NTP technical report on the toxicology and carcinogenesis studies of sodium dichromate dihydrate (CAS No. 7789-12-0) in F344/N rats and B6C3F1 mice (drinking water studies), NTP TR 546. NIH Publication No 085887.

3. Stout MD, Herbert RA, Kissling GE, Collins BJ, Travlos GS, et al. (2009) Hexavalent chromium is carcinogenic to F344/N rats and B6C3F1 mice after chronic oral exposure. Environ Health Perspect 117: 716-722.

4. De Flora S (2000) Threshold mechanisms and site specificity in chromium(VI) carcinogenesis. Carcinogenesis 21: 533-541.

5. Proctor DM, Otani JM, Finley BL, Paustenbach DJ, Bland JA, et al. (2002) Is hexavalent chromium carcinogenic via ingestion? A weight-of-evidence review. J Toxicol Environ Health A 65: 701-746.

6. Liu KJ, Shi X (2001) In vivo reduction of chromium (VI) and its related free radical generation. Mol Cell Biochem 222: 41-47.

7. Salnikow K, Zhitkovich A (2008) Genetic and epigenetic mechanisms in metal carcinogenesis and cocarcinogenesis: nickel, arsenic, and chromium. Chem Res Toxicol 21: 28-44

8. Chiu A, Shi XL, Lee WK, Hill R, Wakeman TP, et al. (2010) Review of chromium (VI) apoptosis, cell-cycle-arrest, and carcinogenesis. Journal of environmental science and health Part C, Environmental carcinogenesis \& ecotoxicology reviews 28: 188-230.

9. Holmes AL, Wise SS, Wise JP Sr (2008) Carcinogenicity of hexavalent chromium. Indian J Med Res 128: 353-372.

10. Nickens KP, Patierno SR, Ceryak S (2010) Chromium genotoxicity: A doubleedged sword. Chem Biol Interact 188: 276-288.

11. O’Brien TJ, Ceryak S, Patierno SR (2003) Complexities of chromium carcinogenesis: role of cellular response, repair and recovery mechanisms. Mutat Res 533: 3-36.

12. Zhitkovich A (2011) Chromium in drinking water: sources, metabolism, and cancer risks. Chemical research in toxicology 24: 1617-1629.

13. Azad N, Iyer AK, Wang L, Lu Y, Medan D, et al. (2010) Nitric oxide-mediated bcl-2 stabilization potentiates malignant transformation of human lung epithelial cells. Am J Respir Cell Mol Biol 42: 578-585.

14. Sun H, Clancy HA, Kluz T, Zavadil J, Costa M (2011) Comparison of gene expression profiles in chromate transformed BEAS-2B cells. PLoS One 6: e17982.

15. Wang X, Son YO, Chang Q Sun L, Hitron JA, et al. (2011) NADPH oxidase activation is required in reactive oxygen species generation and cell transformation induced by hexavalent chromium. Toxicological sciences : an official journal of the Society of Toxicology 123: 399-410.

16. Thompson CM, Haws LC, Harris MA, Gatto NM, Proctor DM (2011) Application of the U.S. EPA mode of action Framework for purposes of guiding future research: a case study involving the oral carcinogenicity of hexavalent chromium. Toxicological Sciences 119: 20-40.

17. NTP (2007) NTP technical report on the toxicity studies of sodium dichromate dihydrate (CAS No. 7789-12-0) administered in drinking water to male and female F344/N rats and B6C3F1 mice and male BALB/c and am3-C57BL/6 mice. NTP Toxicity Report Series Number 72, NIH Publication No 07-5964.

18. De Flora S, D'Agostini F, Balansky R, Micale R, Baluce B, et al. (2008) Lack of genotoxic effects in hematopoietic and gastrointestinal cells of mice receiving chromium(VI) with the drinking water. Mutat Res 659: 60-67.

19. Mirsalis JC, Hamilton CM, O'Loughlin KG, Paustenbach DJ, Kerger BD, et al. (1996) Chromium (VI) at plausible drinking water concentrations is not genotoxic in the in vivo bone marrow micronucleus or liver unscheduled DNA synthesis assays. Environ Mol Mutagen 28: 60-63.

20. Thompson CM, Proctor DM, Haws LC, Hebert CD, Grimes SD, et al. (2011) Investigation of the mode of action underlying the tumorigenic response induced in B6C3F1 mice exposed orally to hexavalent chromium. Toxicological Sciences 123: $58-70$.

21. Ames BN, Shigenaga MK, Gold LS (1993) DNA lesions, inducible DNA repair, and cell division: three key factors in mutagenesis and carcinogenesis. Environmental health perspectives 101 Suppl 5: 35-44.

22. Cohen SM (2010) An enhanced thirteen-week bioassay as an alternative for screening for carcinogenesis factors. Asian Pacific journal of cancer prevention : APJCP 11: 15-17.

23. Slikker W, Jr., Andersen ME, Bogdanffy MS, Bus JS, Cohen SD, et al. (2004) Dose-dependent transitions in mechanisms of toxicity. Toxicol Appl Pharmacol 201: 203-225.

24. McCarroll N, Keshava N, Chen J, Akerman G, Kligerman A, et al. (2010) An evaluation of the mode of action framework for mutagenic carcinogens case study II: chromium (VI). Environ Mol Mutagen 51: 89-111.

\section{Author Contributions}

Conceived and designed the experiments: CMT YF DMP LCH MAH. Performed the experiments: YF DDB. Analyzed the data: CMT YF DDB LK. Contributed reagents/materials/analysis tools: YF DDB. Wrote the paper: CMT YF MS DMP LCH MAH.

25. Kopec AK, Kim S, Forgacs AL, Zacharewski TR, Proctor DM, et al. (2012) Genome-wide gene expression effects in $\mathrm{B} 6 \mathrm{C} 3 \mathrm{~F} 1$ mouse intestinal epithelia following 7 and 90 days of exposure to hexavalent chromium in drinking water. Toxicology and applied pharmacology 259: 13-26.

26. Harris MA, Thompson CM, Wolf JC, Fedorov Y, Hixon JG, et al. (2012) Assessment of Genotoxic Potential of $\mathrm{Cr}(\mathrm{VI})$ in the Intestine via In Vivo Intestinal Micronucleus Assay and In Vitro High Content Analysis in Differentiated and Undifferentiated Caco-2 51st Annual Meeting of the Society of Toxicology. San Francisco, CA.

27. O'Brien TJ, Ding H, Suh M, Thompson CM, Harris MA, et al. (2012) K-Ras codon 12 GGT to GAT mutation is not elevated in the duodenum of mice subchronically exposed to hexavalent chromium in drinking water 51st Annual Meeting of the Society of Toxicology. San Francisco, CA.

28. Greaves P (2007) Histopathology of Preclinical Toxicity Studies. London: Elsevier-Academic Press.

29. Potten CS (1998) Stem cells in gastrointestinal epithelium: numbers, characteristics and death. Philosophical transactions of the Royal Society of London Series B, Biological sciences 353: 821-830.

30. Meunier V, Bourrie M, Berger Y, Fabre G (1995) The human intestinal epithelial cell line Caco-2; pharmacological and pharmacokinetic applications. Cell biology and toxicology 11: 187-194.

31. Natoli M, Leoni BD, D’Agnano I, D’Onofrio M, Brandi R, et al. (2011) Cell growing density affects the structural and functional properties of Caco-2 differentiated monolayer. Journal of cellular physiology 226: 1531-1543.

32. Sambruy Y, Ferruzza S, Ranaldi G, De Angelis I (2001) Intestinal cell culture models: applications in toxicology and pharmacology. Cell biology and toxicology 17: 301-317.

33. Shah P, Jogani V, Bagchi T, Misra A (2006) Role of Caco-2 cell monolayers in prediction of intestinal drug absorption. Biotechnology progress 22: 186-198.

34. Smetanova L, Stetinova V, Svoboda Z, Kvetina J (2011) Caco-2 cells, biopharmaceutics classification system (BCS) and biowaiver. Acta medica 54: 3-8.

35. Rawlinson LA, O'Brien PJ, Brayden DJ (2010) High content analysis of cytotoxic effects of pDMAEMA on human intestinal epithelial and monocyte cultures. Journal of controlled release : official journal of the Controlled Release Society 146: 84-92.

36. Souid-Mensi G, Moukha S, Maaroufi K, Creppy EE (2008) Combined cytotoxicity and genotoxicity of a marine toxin and seafood contaminant metal ions (chromium and cadmium). Environ Toxicol 23: 1-8.

37. Haney SA (2007) High Content Screening. Hoboken: John Wiley \& Sons, Inc.

38. Zanella F, Lorens JB, Link W (2010) High content screening: seeing is believing. Trends in biotechnology 28: 237-245.

39. Bonner WM, Redon CE, Dickey JS, Nakamura AJ, Sedelnikova OA, et al. (2008) GammaH2AX and cancer. Nature reviews Cancer 8: 957-967.

40. Kinner A, Wu W, Staudt C, Iliakis G (2008) Gamma-H2AX in recognition and signaling of DNA double-strand breaks in the context of chromatin. Nucleic acids research 36: 5678-5694.

41. Abraham VC, Towne DL, Waring JF, Warrior U, Burns DJ (2008) Application of a high-content multiparameter cytotoxicity assay to prioritize compounds based on toxicity potential in humans. Journal of biomolecular screening 13: 527-537.

42. Kang K, Oh SH, Yun JH, Jho EH, Kang JH, et al. (2011) A novel topoisomerase inhibitor, daurinol, suppresses growth of HCT116 cells with low hematological toxicity compared to etoposide. Neoplasia 13: 1043-1057.

43. Kopec AK, Thompson CM, Kim S, Forgacs AL, Zacharewski TR (2012) Comparative toxicogenomic analysis of oral $\mathrm{Cr}(\mathrm{VI})$ exposure effects in rat and mouse small intestinal epithelium. Toxicology and applied pharmacology 262: 124-138.

44. OECD (2010) OECD Guideline for the Testing of Chemicals: In Vitro Mammalian Cell Micronucleus Test (\#487). 3rd ed: Organisation for Economic Co-operation and Development.

45. Mondal MS, Gabriels J, McGinnis C, Magnifico M, Marsilje TH, et al. (2010) High-content micronucleus assay in genotoxicity profiling: initial-stage development and some applications in the investigative/lead-finding studies in drug discovery. Toxicological sciences : an official journal of the Society of Toxicology 118: 71-85.

46. Reynolds M, Armknecht S, Johnston T, Zhitkovich A (2012) Undetectable role of oxidative DNA damage in cell cycle, cytotoxic and clastogenic effects of $\mathrm{Cr}(\mathrm{VI})$ in human lung cells with restored ascorbate levels. Mutagenesis.

47. Reynolds M, Stoddard L, Bespalov I, Zhitkovich A (2006) Ascorbate acts as a highly potent inducer of chromate mutagenesis and clastogenesis: linkage to DNA breaks in G2 phase by mismatch repair. Nucleic Acids Res 35: 465-476. 
48. Azzolini C, Fiorani M, Guidarelli A, Cantoni O (2011) Studies with low micromolar levels of ascorbic and dehydroascorbic acid fail to unravel a preferential route for vitamin C uptake and accumulation in U937 cells. The British journal of nutrition: 1-6.

49. Chen Q Espey MG, Krishna MC, Mitchell JB, Corpe CP, et al. (2005) Pharmacologic ascorbic acid concentrations selectively kill cancer cells: action as a pro-drug to deliver hydrogen peroxide to tissues. Proceedings of the National Academy of Sciences of the United States of America 102: 13604-13609.

50. Long LH, Halliwell B (2012) The effects of oxaloacetate on hydrogen peroxed generation from ascorbate and epigallocatechin gallate in cell culture media: potential for altering cell metabolism. Biochem Biophys Res Commun 417: 446450.

51. Crott JW, Fenech M (1999) Effect of vitamin C supplementation on chromosome damage, apoptosis and necrosis ex vivo. Carcinogenesis 20: 1035-1041.

52. Krishnaja AP, Sharma NK (2003) Ascorbic acid potentiates mitomycin Cinduced micronuclei and sister chromatid exchanges in human peripheral blood lymphocytes in vitro. Teratogenesis, carcinogenesis, and mutagenesis Suppl 1: 99-112.

53. Linster CL, Van Schaftingen E (2007) Vitamin C. Biosynthesis, recycling and degradation in mammals. The FEBS journal 274: 1-22.

54. Martensson J, Meister A (1992) Glutathione deficiency increases hepatic ascorbic acid synthesis in adult mice. Proceedings of the National Academy of Sciences of the United States of America 89: 11566-11568.

55. Ha L, Ceryak S, Patierno SR (2004) Generation of S phase-dependent DNA double-strand breaks by $\mathrm{Cr}(\mathrm{VI})$ exposure: involvement of ATM in $\mathrm{Cr}(\mathrm{VI})$ induction of gamma-H2AX. Carcinogenesis 25: 2265-2274.

56. Nkabyo YS, Ziegler TR, Gu LH, Watson WH, Jones DP (2002) Glutathione and thioredoxin redox during differentiation in human colon epithelial (Caco-2) cells. American journal of physiology Gastrointestinal and liver physiology 283: G1352-1359.

57. Covacci V, Torsello A, Palozza P, Sgambato A, Romano G, et al. (2001) DNA oxidative damage during differentiation of HL-60 human promyelocytic leukemia cells. Chemical research in toxicology 14: 1492-1497.

58. Zhang Z, Leonard SS, Wang S, Vallyathan V, Castranova V, et al. (2001) Gr (VI) induces cell growth arrest through hydrogen peroxide-mediated reactions. Mol Cell Biochem 222: 77-83.

59. El Hassani RA, Benfares N, Caillou B, Talbot M, Sabourin JC, et al. (2005) Dual oxidase2 is expressed all along the digestive tract. American journal of physiology Gastrointestinal and liver physiology 288: G933-942.
60. Katsuyama M (2010) NOX/NADPH oxidase, the superoxide-generating enzyme: its transcriptional regulation and physiological roles. Journal of pharmacological sciences 114: 134-146.

61. Thompson CM, Proctor DM, Suh M, Haws LC, Hebert CD, et al. (2012) Comparison of the effects of hexavalent chromium in the alimentary canal of F344 rats and $\mathrm{B} 6 \mathrm{C} 3 \mathrm{~F} 1$ mice following exposure in drinking water: implications for carcinogenic modes of action. Toxicological sciences : an official journal of the Society of Toxicology 125: 79-90.

62. Brooks B, O'Brien TJ, Ceryak S, Wise JP, Sr., Wise SS, et al. (2008) Excision repair is required for genotoxin-induced mutagenesis in mammalian cells. Carcinogenesis 29: 1064-1069.

63. Ewald B, Sampath D, Plunkett W (2007) H2AX phosphorylation marks gemcitabine-induced stalled replication forks and their collapse upon S-phase checkpoint abrogation. Molecular cancer therapeutics 6: 1239-1248.

64. Tanaka T, Halicka HD, Huang X, Traganos F, Darzynkiewicz Z (2006) Constitutive histone H2AX phosphorylation and ATM activation, the reporters of DNA damage by endogenous oxidants. Cell Cycle 5: 1940-1945.

65. Proctor DM, Suh M, Aylward LL, Kirman CR, Harris MA, et al. (in press) Hexavalent chromium reduction kinetics in rodent stomach contents. Chemosphere.

66. Wicki A, Herrmann R, Christofori G (2010) Kras in metastatic colorectal cancer. Swiss medical weekly 140: w13112.

67. Cohen SM, Gordon EB, Singh P, Arce GT, Nyska A (2010) Carcinogenic mode of action of folpet in mice and evaluation of its relevance to humans. Crit Rev Toxicol 40: 531-545.

68. U.S EPA (2004) Captan; Cancer Reclassification; Amendment of ReregistrationEligibility Decision; Notice of Availability. Federal Register 69: 6835768360 .

69. Rzymski T, Milani M, Singleton DC, Harris AL (2009) Role of ATF4 in regulation of autophagy and resistance to drugs and hypoxia. Cell Cycle 8: 3838-3847.

70. Kinoshita A, Wanibuchi H, Imaoka S, Ogawa M, Masuda C, et al. (2002) Formation of 8-hydroxydeoxyguanosine and cell-cycle arrest in the rat liver via generation of oxidative stress by phenobarbital: association with expression profiles of p21(WAF1/Cip1), cyclin D1 and Ogg1. Carcinogenesis 23: 341-349.

71. Carvalho PS, Catian R, Moukha S, Matias WG, Creppy EE (2006) Comparative study of Domoic Acid and Okadaic Acid induced-chromosomal abnormalities in the Caco-2 cell line. International journal of environmental research and public health 3: 4-10. 